\title{
How a New Paradigm Explains Topographic Map Drainage System and Erosional Landform Evidence in the Fremont County Royal Gorge Area, Colorado, USA
}

\author{
Eric Clausen ${ }^{1}$ \\ ${ }^{1}$ Jenkintown, PA, USA 19046 \\ Correspondence: Eric Clausen, Jenkintown, PA, USA 19046. E-mail: eric2clausen@ gmail.com
}

Received: November 13, 2021

Accepted: November 27, 2021

Online Published: November 30, 2021

doi: 10.5539/jgg.v13n2p32

URL: https://doi.org/10.5539/jgg.v13n2p32

\begin{abstract}
A new Cenozoic geologic and glacial history paradigm (new paradigm) describes massive and prolonged continental ice sheet meltwater floods that eroded the Colorado Royal Gorge area and surrounding regions and which were diverted in east, northeast, and even north directions as uplift of a thick ice sheet created deep "hole" rim gradually occurred (the thick ice sheet was located where North American ice sheets are usually recognized to have existed). A deep "hole" rim segment followed what is now the northern and central Colorado east-west continental divide southward to the Arkansas River headwaters area and then continued south along the Sangre de Cristo Mountains crestline to at least the Purgatoire River-Canadian River drainage divide and may have continued east from that point along a less well-defined zone beginning with what is now the Purgatoire River-Canadian River drainage divide. Diverging and converging valley complexes, barbed tributaries, and Arkansas River and other drainage route direction changes (easily seen on United States Geological Survey detailed topographic maps) are interpreted to have developed as the south-oriented floodwaters first flowed across the rising deep "hole" rim to reach the south- and southeast-oriented Rio Grande River drainage basin and were subsequently blocked by deep "hole" rim uplift and diverted to flow in east, northeast, and north directions. The accepted Cenozoic geologic and glacial history paradigm (accepted paradigm) has to date been unable to satisfactorily explain the detailed topographic map drainage system and erosional landform evidence and the new and accepted paradigms are incommensurable and lead to quite different Cenozoic geologic and glacial histories.
\end{abstract}

Keywords: Arkansas River, Canadian River, Deep "hole" rim location, Purgatoire River, Sangre de Cristo Mountains, Wet Mountain Valley

\section{Introduction}

\subsection{Statement of the Problem}

Royal Gorge is a 450- to 500-meter-deep narrow canyon in southcentral Colorado's Fremont County where the southeast-oriented Arkansas River has sliced a deep and narrow valley into uplifted Precambrian rocks forming what geologists refer to as the Royal Gorge Arch (see figure 1 for the location). Clarey et al (2004, p, 18-19) describe the Royal Gorge Arch as "one of three large basement-cored uplifts at the southern end of the Front Range" and as being "a broad anticlinal fold, with sedimentary rocks dipping steeply on the eastern flank and gently on the western flank." Thornbury (1965, p. 330) describes the Arkansas River as one of a "large number of [Rocky Mountain] streams that flow directly across mountain uplifts through deep gorges" and adds (p. 349) "The course of the stream here undoubtably antedates the uplift of the Colorado Front Range and probably represents another example of superposition, although remnants of the cover mass from which it may have been superposed are lacking."

While rarely described as such Royal Gorge and the many deep canyons and gorges cut across other Rocky Mountain uplifts are examples of what Thomas Kuhn (1970) regards as anomalous evidence. The Royal Gorge evidence is well known and has been described, but to date the accepted Cenozoic geologic and glacial history paradigm (accepted paradigm) has not enabled researchers to satisfactorily explain most Royal Gorge region drainage system and erosional landform evidence. Instead, researchers without saying so assume erosion occurred over long periods of time and removed all of the cover mass evidence and/or assume future geomorphologists will better explain the Royal Gorge origin. Surprisingly, published reports in which Royal Gorge region drainage 
history is discussed do not mention most of the easily observed drainage system and erosional landform evidence found on United States Geological Survey (USGS) detailed topographic maps. Detailed topographic maps show the Arkansas River making difficult to explain direction changes and joined by numerous equally difficult to explain barbed tributaries. Further, Royal Gorge area topographic maps show dry valleys crossing present-day drainage divides which when combined with existing stream valleys form hard to explain diverging and converging valley complexes. While maybe providing debatable explanations for a few of the difficult to explain features, accepted paradigm explanations have yet to explain these drainage system and erosional landform features as a group.

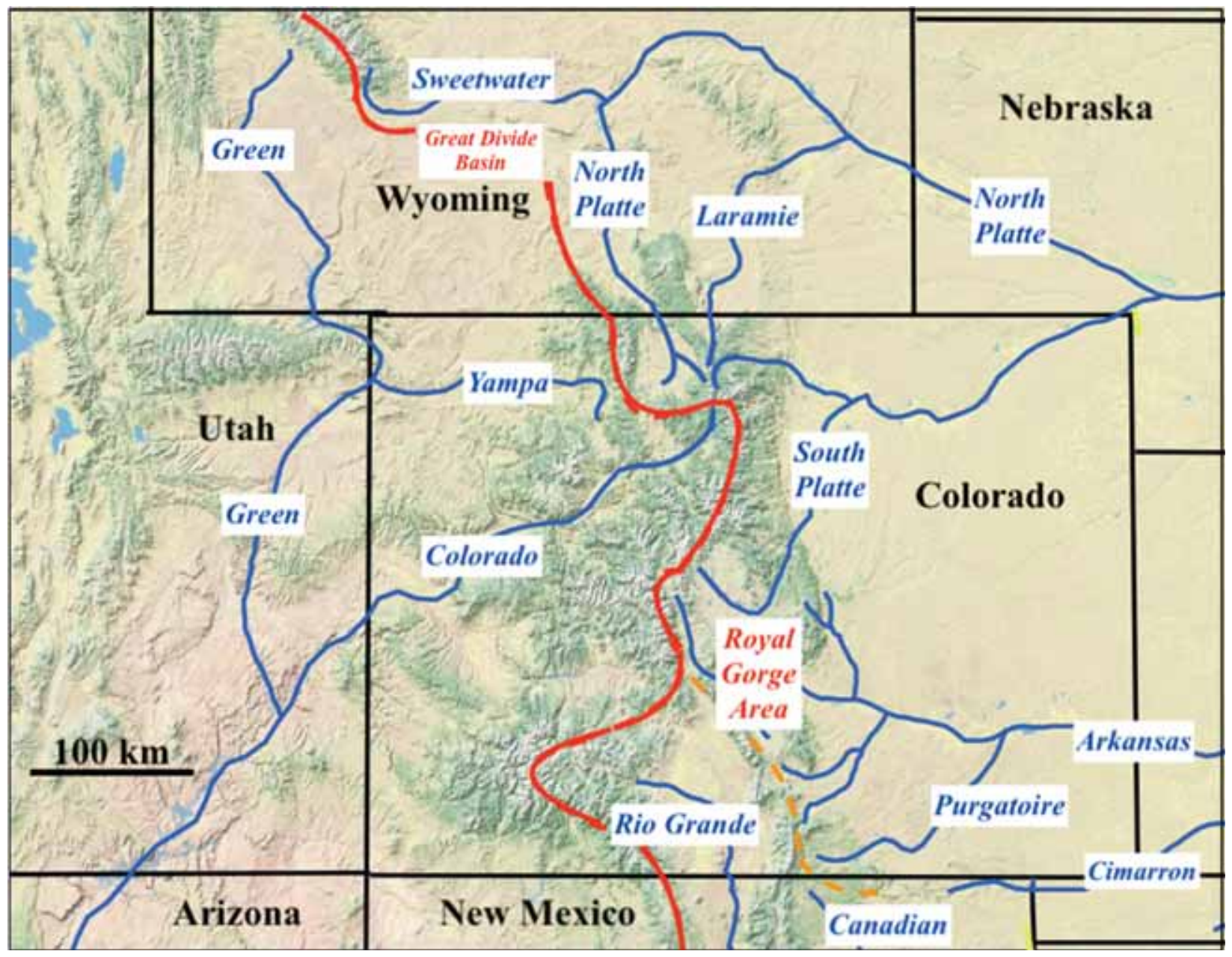

Figure 1. Modified map from the United States Geological Survey (USGS) National Map website showing the Royal Gorge area location in relation to regional rivers, the east-west continental divide (solid red line) and the deep "hole" rim extending around the Arkansas River drainage basin and along Sangre de Cristo Mountain crestline (orange dashed line).

In an effort to correct accepted paradigm problems the author of this paper used Missouri River drainage basin topographic map drainage system and erosional landform evidence to construct a new Cenozoic geologic and glacial history paradigm (new paradigm) able to explain the detailed topographic map drainage system and erosional landform evidence (Clausen, 2020a). The resulting new paradigm requires all Missouri River drainage basin valleys which are large enough to show on USGS 1:24,000 scale topographic maps to have been eroded along or across massive and prolonged floods which flowed across rising mountain ranges. The south-oriented floods originated where continental ice sheets are usually reported to have existed, but were systematically diverted by Rocky Mountain uplift to flow in southeast directions and were eventually captured in sequence (from the southeast to the northwest) by headward erosion of northeast- and north-oriented valleys from the continental ice sheet location. In brief, the new paradigm requires a thick continental ice sheet which was located where ice sheets 
are usually reported to have been and heavy enough to create and occupy (probably by a combination of deep ice sheet erosion and of ice sheet caused surrounding region uplift) a deep "hole" (the accepted paradigm does not recognize an ice sheet created deep "hole").

Important to this paper is the new paradigm's deep "hole" rim which was uplifted as meltwater floods flowed across it and the Montana, Wyoming and northern Colorado east-west continental divide represents an easily identified deep "hole" southwestern rim segment. Topographic map evidence from the Arkansas River drainage basin was not used in the new paradigm development process and for this reason in previous publications this author has speculated the deep "hole" rim may have extended eastward from the Colorado east-west continental divide near what is now the Missouri River-Arkansas River drainage divide. In addition to demonstrating how the new paradigm explains previously unexplained Royal Gorge area Arkansas River direction changes, barbed tributaries, and dry valleys the study reported here also sought to use detailed topographic map evidence to test whether the new paradigm's deep "hole" rim turned east near the present-day Missouri River-Arkansas River drainage divide as this author has suggested (e.g. Clausen 2021a, p. 4) or continued in a southward direction along the Sangre de Cristo Mountains crestline before turning in an east direction and perhaps more logically being located nearer to what is now the Mississippi River-Rio Grande River drainage divide.

\subsection{Geographical Setting}

The Royal Gorge study area is located in figure 1 although to determine the deep "hole" rim location the study reported here also investigated detailed topographic maps covering the larger western Arkansas River drainage basin (seen in figure 2). To the north and west of the Royal Gorge area the deep "hole" rim location has previously been determined to follow the east-west continental divide (shown in figures 1 and 2 with a solid red line). A probable deep "hole" rim location (shown in figures 1 and 2 with a dashed orange line) determined in the study described here follows the Arkansas River drainage basin's western boundary along the Sangre de Cristo Mountain crestline southward to about the present-day Colorado-New Mexico state line and then may turn in an east direction between the southeast- and northeast-oriented Purgatoire River and south- and east-oriented oriented Canadian River (both of which reach the Arkansas River). The deep "hole rim location for most of the distance between figure 1 and the Mississippi River is yet to be determined, although after deep "hole" rim uplift the south-oriented Mississippi River valley became the only southern deep "hole" exit. To the east of the Mississippi River valley the deep "hole" rim location probably follows the present-day Ohio River (Tennessee River)-Gulf of Mexico drainage divide and the Ohio River-Atlantic Ocean drainage divide.

Immediately to the north of the Royal Gorge area are southeast and north-northeast oriented South Platte River headwaters. Southeast-oriented South Platte River headwaters like south-oriented Arkansas River headwaters begin at high mountain passes located along the east-west continental divide and further to the north and across the now deep southwest-oriented Colorado River headwaters valley and north of an east-to-west oriented continental divide segment are north-oriented North Platte, Laramie, and Cache la Poudre River headwaters. The Cache la Poudre River (shown but not labelled in figure 1) turns in an east direction to join the South Platte River while the north-oriented North Platte River flows into central Wyoming before turning in a southeast direction to join the Laramie River and then the South Platte River and to form the east-oriented Platte River. Prior to the deep "hole" rim uplift the new paradigm sees large and prolonged south-oriented meltwater floods flowing from today's north-oriented North Platte and Laramie River drainage basins across what is now the southwest-oriented Colorado River headwaters drainage basin and the now high continental divide (twice) and then across the South Platte River headwaters area to reach today's Arkansas River drainage basin.

The western Arkansas River drainage basin is shown in figure 2 as well as its relationship to the southeast and north-northeast oriented South Platte River headwaters. The east-west continental divide is shown with a solid red line and a dashed orange line shows a probable deep "hole" rim location (described in the results section below) along the Sangre de Cristo Mountain crestline and then eastward along the Purgatoire River drainage basin southern margin. The south-oriented Rio Grande River drainage basin is south and west of the deep "hole" rim. Note how Grape Creek flows in a north direction through the Wet Mountain Valley (unnamed in figure 2) between the Sangre de Cristo and Wet Mountains and across the Wet Mountains to reach the southeast-oriented Arkansas River as a barbed tributary (at Royal Gorge). The southeast- and northeast-oriented Huerfano River, northeastoriented Cucharas River, and further north an unnamed in figure 2 north-oriented stream (Texas Creek) also drain the Wet Mountain Valley. North of Royal Gorge south-oriented Currant and Fourmile Creeks are Arkansas River tributaries originating along the South Platte River-Arkansas River drainage divide. 


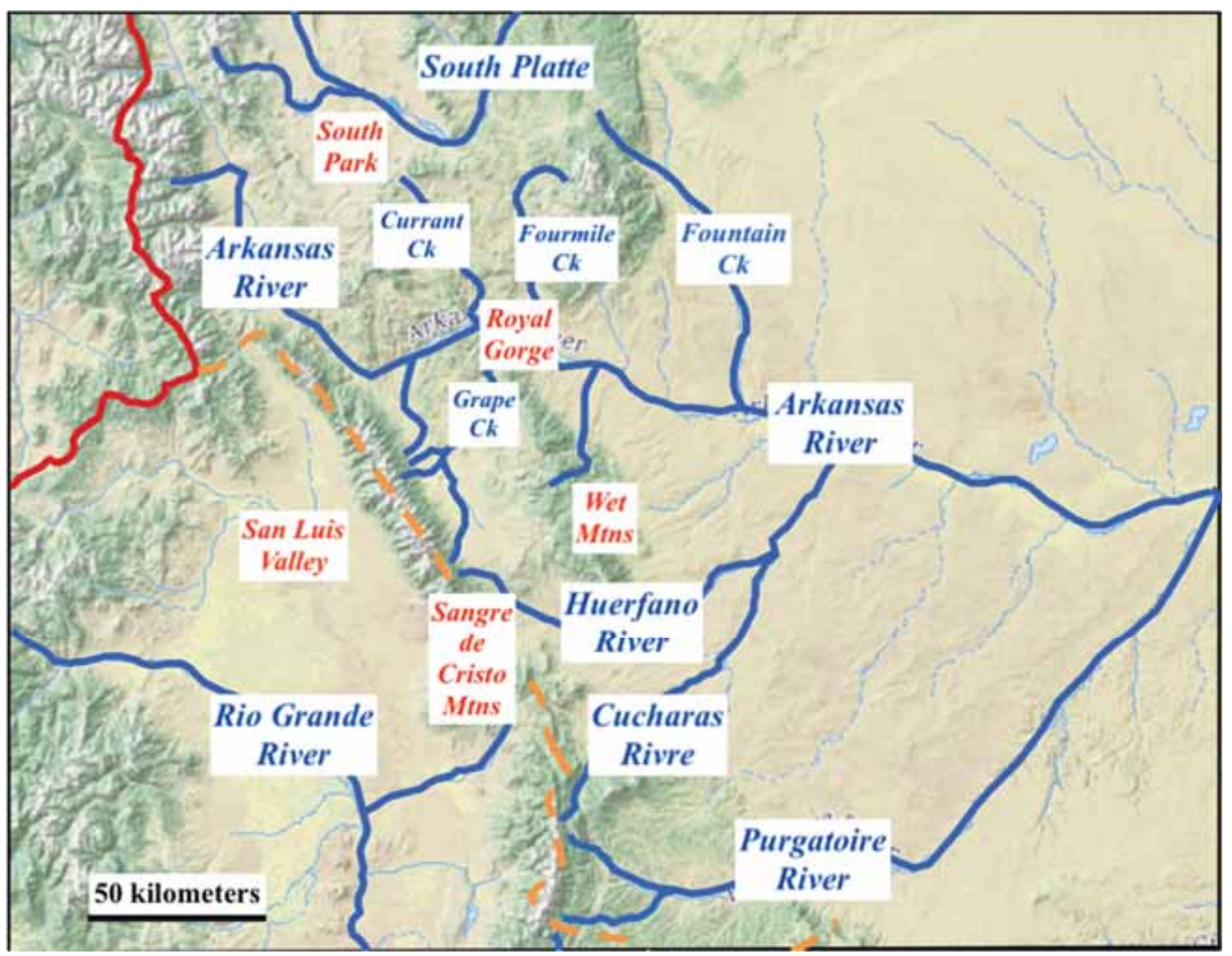

Figure 2. Modified map from the USGS National Map website showing how the deep "hole" rim (dashed orange line) extends in a south-southeast direction from the east-west continental divide (solid red line) along the Sangre de Cristo Mountain crestline before turning in an east direction.

\subsection{Previous Accepted Paradigm Interpretations}

While considerable published literature describes Royal Gorge area geologic features little of that literature addresses the regional drainage history. Fenneman (1931, p. 110) in a summary of late $19^{\text {th }}$ and early $20^{\text {th }}$ century literature notes the Arkansas River course may have been established "while the granite was still covered by the strata now outcropping in the foothills, and before the broad valley of the upper Arkansas was cut. This would make the river consequent on the covering beds and superposed on the granite." He goes on "It is not yet known to what extent the river was thus guided by slopes which the water found rather than made, and to what extent it maintained a preexisting course by cutting down into the mountains that rose across it." Powers (1935) described Arkansas River terraces and suggested a late Pliocene age for the low relief surface into which Royal Gorge is cut, although he did not address Arkansas River direction changes, barbed tributaries, or nearby diverging and converging valley systems. Atwood (1940, p. 336) in a comment focused on Royal Gorge alone says "Perhaps the mountains are rising and thus forcing the stream to continue its downward cutting. This would help to account for the narrowness of the gorge and its nearly vertical walls," although he also does not address the Arkansas River direction changes, barbed tributaries or diverging and converging valley complexes. Early workers also devoted considerable attention to arguing about what they saw as regional erosion surfaces $(e . g$. Van Tuyl and Lovering, 1935).

Leonard et al (2002, p 69) in a field guidebook pertaining to areas now drained by the South Platte and Arkansas Rivers comment “Work in the 1960's and 1970's by Rudy Epis, Glen Scott, Richard Taylor, Charles Chapin and their colleagues remains the basis of our understanding of drainage history." The guidebook includes a discussion of Royal Gorge where Leonard et al note "Very little has been written about this spectacular canyon. The course 
of the Arkansas River changes abruptly from NE to SE on the eastern edge of Webster Park, where it cuts into Proterozoic granodiorite, quartz diorite and gneiss across Proterozoic foliation and Laramide and younger structural trends to form the gorge. The canyon is incised into a plateau developed on crystalline rocks and locally capped by Jurassic sedimentary rocks (Taylor et al, 1975), suggesting it may represent exhumed Ancestral Rockies topography." They go on to add "The timing and causes of the cutting of the Royal Gorge remain uncertain and relatively unstudied." Continuing they comment "Scott and Epis (1977) suggest that cutting of the gorge resulted from both uplift and increased river discharge due to the integration of the upper Arkansas River (above Salida) into the drainage in the Pliocene." Earlier in the field guide (p. 70) Leonard et al note Epis et al (1976) claim "paleodrainage in the upper Arkansas River valley crossed Poncha Pass and drained into the San Luis basin" although "Knepper (1976) maintained that the upper Arkansas valley has always been distinct from the San Luis valley" and Leonard et al continue by saying "In either case, there does not appear to have been Miocene flow from the upper Arkansas valley southeastward and eastward down the modern course of the river."

The Southern Rocky Mountain region erosion surface origin problem is summarized by Pazzaglia and Kelley (1998, p. 231) who say "the core of the debate surrounding the Cenozoic tectonic evolution of the Southern Rockies centers on whether this erosion surface was (1) created by progressive lowering and rounding of divides of a formerly high-standing Laramide upland as the landscape was reduced to near sea level (Davis, 1911; Love, 1970), (2) created near sea level as fluvial erosion kept pace with the uplift of rock during Laramide deformation (Epis et al., 1980), or (3) created at high elevation (2 to $2.5 \mathrm{~km}$ ) by a climate and hydrology that favored the reduction of relief in the uplands (Gregory and Chase, 1994)." Without describing how Rocky Mountain stream integration occurred Pazzaglia and Kelley (p. 229) suggest "Proterozoic crustal structure, Laramide deformation, and postLaramide uplift, appear to play an important role in the ability of streams to integrate through the Rocky Mountain foreland. As rates of erosion are strongly tied to local relief ...stream integration at the large scale may explain the correlation between long-term denudation rates and modern topographic ruggedness." In a more recent study aimed at constraining the magnitude and timing of Laramide deformation in the Arkansas River valley region (upstream from Royal Gorge) Abbey et al (2018, p. 262) discuss how mid-Cenozoic volcanism preserved the eastern Arkansas River valley region late Eocene topography and suggest "The only major landscape development that has occurred from the middle Cenozoic to present in the LAR [Lower Arkansas River] valley region is the $>1$ $\mathrm{km}$ of modern river incision, which may have been accelerated by a combination of re-incising a paleovalley through headward erosion from east to west and stream capture aided by Rio Grande rifting to the west." Remarkably none of the above cited accepted paradigm researchers report using topographic map evidence to reconstruct former drainage routes.

\subsection{Previous New Paradigm Interpretations}

Clausen (the author of this paper) is the only known researcher to have published papers in which the new paradigm has been used to explain detailed topographic map evidence. To date he has published demonstration papers (similar to this paper) in which the new paradigm is used to explain detailed topographic map drainage system and erosional landform evidence in 27 specific and different Missouri River drainage basin locations including the South Platte River headwaters region immediately to the north of this paper's Royal Gorge study area (Clausen, 2021a). That paper discusses and illustrates topographic map evidence showing the valley in which the South Platte River now flows in a north direction (which is north of the Royal Gorge area-see figure 1) originated as a series of diverging and converging south-oriented flood flow channels (which were joined by what were southeastoriented flood flow channels). That paper discusses and illustrates topographic map evidence for large complexes of diverging and converging channels crossing the present-day South Platte River-Arkansas River drainage divide and leading to what are now the Currant, Fourmile, and Fountain Creek drainage basins

Additional new paradigm demonstration papers used detailed topographic map evidence to reconstruct the North and South Platte River drainage history. In a paper pertinent to this study Clausen (2020b) discusses how mountain passes crossing what are now east-west continental divide segments surrounding the southwest-oriented Colorado River headwaters drainage basin record how (prior to mountain range uplift and Colorado River valley headward erosion) massive and prolonged south- and southeast-oriented floods flowed from what is now the north-oriented North Platte River headwaters drainage basin across what is now the Colorado River headwaters drainage basin to reach the north-oriented South Platte River headwaters drainage basin. Clausen (2021b) describes how evidence on detailed topographic maps shows how large south-oriented floods flowing in what is now the north-oriented North Platte River headwaters drainage basin were forced by mountain range uplift to make a U-turn and to flow in a north direction along the present-day Laramie River alignment into the Laramie Basin and then to flow through what is now a Laramie Range diverging and converging canyon complex (described in Clausen, 2018) to reach the southeast-oriented North Platte River. And, Clausen (2019a) describes how headward erosion of the southeast- 
oriented North Platte River valley beheaded and reversed south-oriented flood flow channels which had been moving large volumes of water southward across the rising northern Laramie Mountains and eventually caused a reversal of south-oriented flood flow to create the north-oriented North Platte River headwaters. These and several other new paradigm demonstration papers have explained significant amounts of the North and South Platte River drainage basin detailed topographic map drainage system and erosional landform evidence.

\section{Research Method}

Topographic maps and tools available at the USGS National Map website without question represented the most important reference work used in the study reported here. The detailed topographic maps were originally prepared at a scale of 1:24,000 and with contour intervals ranging from about 3 to 15 meters and record in a paradigm neutral form all of the regional drainage routes and erosional landscape features (subject to the map scale and contour interval). One useful USGS National Map website feature was the ability to observe less detailed topographic maps covering large areas and then to switch to the most detailed topographic maps on which landforms of interest were located. In addition, once focused on a large landform the detailed topographic maps could be easily scrolled so as to completely view the large landform. While these USGS National Map website features may seem commonplace to younger geomorphologists these features enabled much more rapid and efficient topographic map interpretation than was possible when topographic map interpreters relied on hard copy topographic maps (which was the case for almost all of the $20^{\text {th }}$-century).

Research reported here began by scanning less detailed USGS National Map website topographic maps to identify Arkansas River direction changes, barbed tributaries, and diverging and converging valley evidence in the Royal Gorge area and then in the much larger western Arkansas River drainage basin (located in the Rocky Mountain region). Topographic maps covering the area between the South Platte River-Arkansas River drainage divide and Arkansas River were first studied to identify evidence (in the form of diverging and converging valley complexes) for large south-oriented floods which Clausen (2021a) showed had flowed across the present-day South PlatteArkansas River drainage divide to enter the present-day Currant Creek, Fourmile Creek, and Fountain Creek drainage basins. Valleys including southeast-oriented Arkansas River valley segments and the northeast-oriented Arkansas River valley segment (upstream from Royal Gorge) were next interpreted to have been eroded as channels in a large south-oriented diverging and converging channel complex (with the northeast-oriented Arkansas River valley segment originating as a southwest-oriented flood flow channel).

Less detailed topographic maps covering the western Arkansas River drainage basin were also scanned to identify south-oriented diverging and converging channel evidence that extends to the south of the south-, southeast-, northeast-, and southeast-oriented Arkansas River valley. North-oriented tributary valleys now draining to the Arkansas River (including the northeast-oriented Arkansas River valley segment) were interpreted to have originated as southern extensions of the previously identified south-oriented flood-formed diverging and converging channel complex and are linked by divide crossings (low points along drainage divides) with southoriented drainage routes still further to the south. The Arkansas-Rio Grande River and Purgatoire-Canadian River drainage divides were studied as described in the results section below to identify points where multiple streams of south-oriented water flowed from one drainage basin into adjacent drainage basins in an effort to identify where the new paradigm's deep "hole" rim continued to the southeast and east of the east-west continental divide.

\section{Results}

\subsection{Royal Gorge Area Topographic Map Drainage System and Erosional Landform Evidence}

Figure 3 illustrates typical topographic map drainage system and erosional landform evidence found throughout the larger Royal Gorge region while figure 4 provides a generalized drainage system map for the larger Royal Gorge area. At Royal Gorge the Arkansas River has carved a spectacular water gap across uplifted Precambrian bedrock while Temple Canyon is where north-oriented Grape Creek turns in a northeast direction to flow through a somewhat less spectacular water gap before reaching the Arkansas River. Numbers 1-4 in figure 3 identify through valleys (dry valleys crossing drainage divides) which when combined with the present-day active stream and river valleys form a large complex of diverging and converging valleys. Barbed tributaries join larger streams sometimes at river and stream direction change locations. For example, Bumpback Gulch drains in a southwest direction to where the Arkansas River turns from flowing in a northeast direction to flow in a southeast direction (before reaching Royal Gorge). Volcano Creek flows in a south direction from the Grand Canyon Hills to join Grape Creek as a barbed tributary near where Grape Creek turns from flowing in a north direction to flow in a northeast direction. These erosional features are difficult or impossible to explain from an accepted paradigm perspective, yet the features exist and something formed them. 


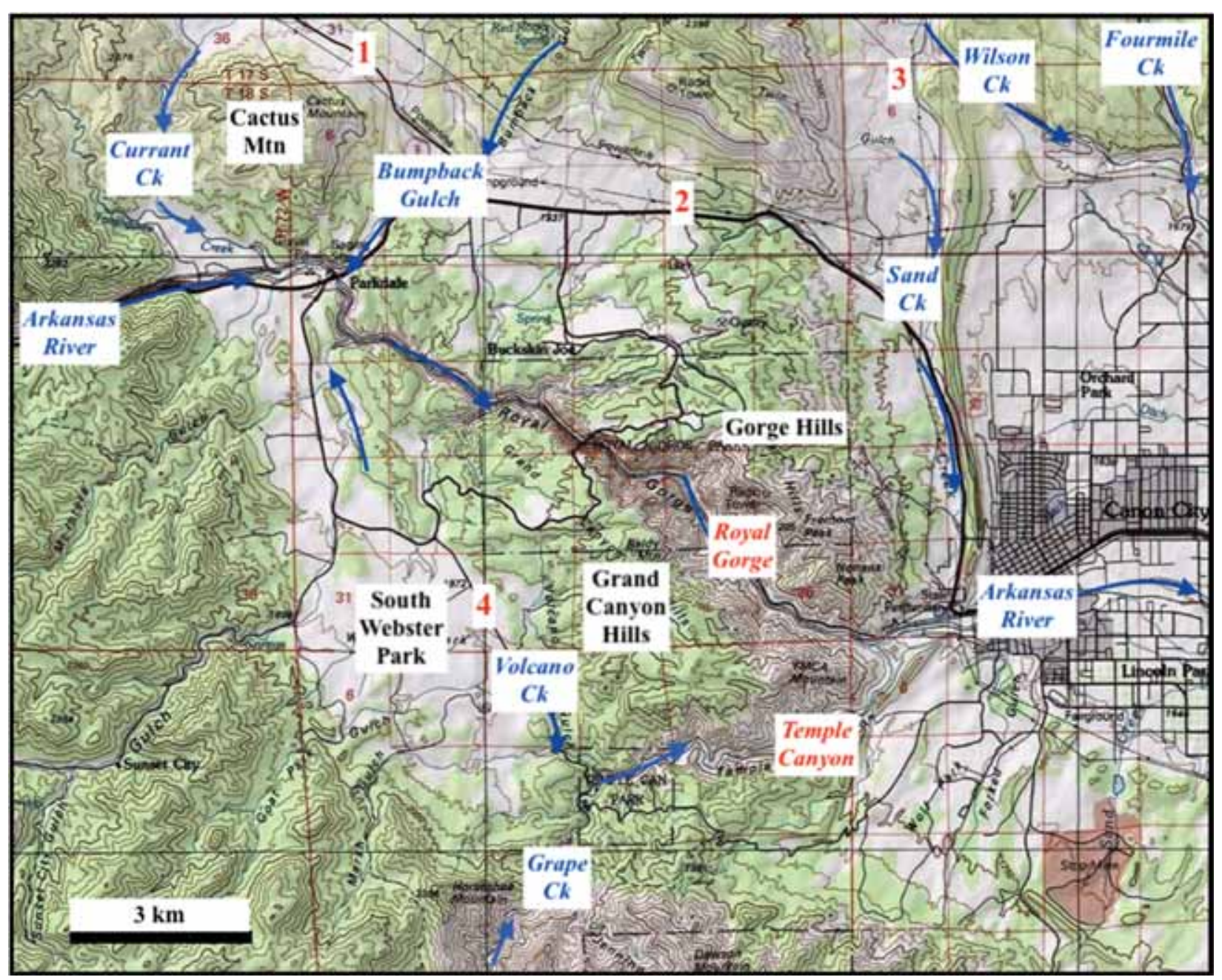

Figure 3. Modified topographic map from the USGS National Map website showing Royal Gorge area landforms and with blue arrows showing present-day drainage route directions. Numbers identify locations discussed in the text. The contour interval is 50 meters.

From a new paradigm perspective all valleys seen in figure 3 including what are now dry valleys at the figure 3 locations 1-4 can be explained if those valleys were all eroded at the same time as components of a large southoriented flood formed diverging and converging channel complex. The through valley at number 1 links southoriented Currant Creek with the southwest-oriented Bumpback Gulch and was eroded by water diverging from the Currant Creek valley to join south-oriented flow on the Bumpback Creek alignment and to also to flow in the now dry valley identified by number 2 to join south-oriented water on the Sand Creek alignment. Number 3 identifies a somewhat shallower dry valley between southeast-oriented Wilson Creek (flowing to south-oriented Fourmile Creek) and south-oriented Sand Creek. Number 4 identifies a much larger dry valley extending in a southeast direction from where Currant Creek now joins the Arkansas River to the Grape Creek valley, where Grape Creek turns from having a north direction to a northeast direction. Today's north-oriented Grape Creek valley originated as a south-oriented flood flow channel with southeast-oriented water flowing in the valley identified by number 4 joining southwest-oriented water eroding Temple Canyon to flow in a south direction across the Wet Mountains and into the Wet Mountain Valley (see figure 4). Regional and mountain range uplift later caused a drainage reversal, which resulted in north-oriented water flowing through Temple Canyon to reach the southeast-oriented Arkansas River. 




Figure 4. Modified map from the USGS National Map website showing major drainage routes in the region south and west of the figure 3 Royal Gorge area. Note how Grape Creek and other drainage routes including the northeast-oriented Arkansas River segment flow across the Wet Mountains before joining the downstream southeast- and east-oriented Arkansas River.

Clausen (2021a) describes south-oriented diverging and converging channel complexes crossing the South Platte River-Arkansas River drainage divide to the north of figure 3 and leading to the south-oriented Currant Creek and Fourmile Creek drainage basins. The through valley at the figure 3 location 1 indicates south-oriented floodwaters in the Currant Creek valley diverged to the north of Cactus Mountain with one channel continuing to the north of the Gorge Hills in the through valley at location 2 to join south-oriented water along the Sand Creek alignment while another channel continued in a south direction along the Currant Creek route west of Cactus Mountain to where the Arkansas River now changes from flowing in a northeast direction to flow in a southeast direction (to reach Royal Gorge). At that Arkansas River direction change a southeast channel diverged from the southsoutheast oriented Currant Creek channel and eroded the Royal Gorge canyon across what was probably a rising geologic structure and a southwest-oriented channel diverged and carved the upstream (now northeast-oriented) Arkansas River valley segment while a south-southeast oriented flood flow channel continued along the dry valley at location 4 and after joining southwest-oriented water that was beginning to erode Temple Canyon continued southward across the Wet Mountains (which were probably beginning to be uplifted) along the north-oriented Grape Creek alignment to the Wet Mountain Valley (which is located between the Sangre de Cristo Mountains and Wet Mountains). 
Today the Sangre de Cristo Mountains form a high barrier between the Wet Mountain Valley and the San Luis Valley (in the south-oriented Rio Grande River drainage basin). While early on south-oriented floodwaters on the Grape Creek alignment may have crossed the rising Sangre de Cristo Mountains to reach the Rio Grande River drainage basin mountain uplift soon blocked those routes and forced the floodwaters to join south-southeast oriented floodwaters which had entered the northern Wet Mountain valley from the north. Floodwaters from the north had flowed in southeast and southwest directions to converge (where the Arkansas River now turns from a southeast direction to a northeast direction near the figure 4 center). Other south-oriented floodwaters from the north had diverged from the southwest-oriented channel to flow along the now north-oriented Texas Creek alignment. Floodwaters then flowed in a south-southeast direction in the Wet Mountain Valley along the now north-northwest oriented Grape Creek headwaters alignment (seen in figure 4) and finally across what is now Promontory Divide to reach the present-day southeast-oriented Huerfano River headwaters (see figure 2). Today the Huerfano River, after flowing in a southeast direction turns to flow in a northeast direction, which suggests northeast-oriented Huerfano River valley headward erosion diverted south-southeast oriented floodwaters in a northeast direction to reach the Arkansas River and that deep "hole" rim uplift reversed the flow to create northoriented drainage routes seen today.

Detailed topographic maps show evidence of diverging and converging valley complexes throughout the entire region. For example, the detailed topographic map in figure 5 illustrates how diverging and converging valleys surround Griddle Mountain (located north and west of Cactus Mountain which is seen in figure 3). Note how the south-oriented Currant Creek valley is located east of Griddle Mountain, but how an unnamed south-oriented valley diverges at location 5 (and crosses a low drainage divide) and proceeds in a south direction along the Griddle Mountain west side to join southeast-oriented Sand Gulch and then Cottonwood Creek (which joins Currant Creek to the south of the figure). Cottonwood Creek flows in a southeast direction to reach the figure 5 map area and jogs in a south direction even though a dry valley (location 6) continues in an east-southeast direction across a low drainage divide to reach the south-oriented Sand Gulch valley. Location 7 identifies a dry valley linking southwestoriented Webster Gulch with south-oriented Wilson Creek headwaters (located north and east of the figure). Wilson Creek is a south- and southeast-oriented Fourmile Creek tributary (see figure 4). Location 8 identifies a dry valley, which is a southwest extension of the Webster Gulch Valley now crossing the Griddle Mountain highland and which headward erosion of the deeper south-oriented Currant Creek channel beheaded. Headward erosion of deeper channels in flood formed diverging and converging channels complexes repeatedly captured and/or beheaded shallower channels (sometimes causing drainage reversals) leaving what now appear to be anomalous drainage route direction changes, barbed tributaries, and dry valleys crossing drainage divides.

\subsection{Deep "Hole" Rim Location to the South of the Royal Gorge Area}

The deep "hole" rim location follows the east-west continental divide in southern Canada, Montana, Wyoming, and northern Colorado, but the rim location is not as easily identified between the Rocky Mountains and the Mississippi valley. While this author has speculated the deep "hole" rim continued eastward from the central Colorado east-west continental divide near what is now the Missouri River-Arkansas River drainage divide, a better and more logical deep "hole" rim location might be near what is now the Arkansas River-Gulf of Mexico drainage divide (which would locate the deep "hole rim near the Arkansas River drainage basin southern margin). As seen in figures 1 and 2 the Arkansas River originates to the north of the San Luis Valley and flows in a south direction in what Kellogg et al (2013, p. 4) show as a possible northern extension of the Rio Grande rift before turning in southeast, northeast, and southeast directions to reach the Royal Gorge area. Poncha Pass (seen in figure 4) links the south-oriented San Luis Valley (draining to the Rio Grande River) and the north-oriented Poncha Creek valley (draining to near the town of Salida where the south-oriented Arkansas River now turns in a southeast direction). Poncha Pass is a 500-meter deep or deeper low point on the Arkansas River-Gulf of Mexico drainage divide and was probably eroded into what must have been rising mountains by large volumes of south-oriented floodwater that were being split into diverging channels by the rising Sangre de Cristo Mountains (with one channel flowing through Poncha Pass to enter the San Luis Valley and reach the south-oriented Rio Grande River while another channel at first flowed in a southeast direction to enter the Wet Mountain Valley). 


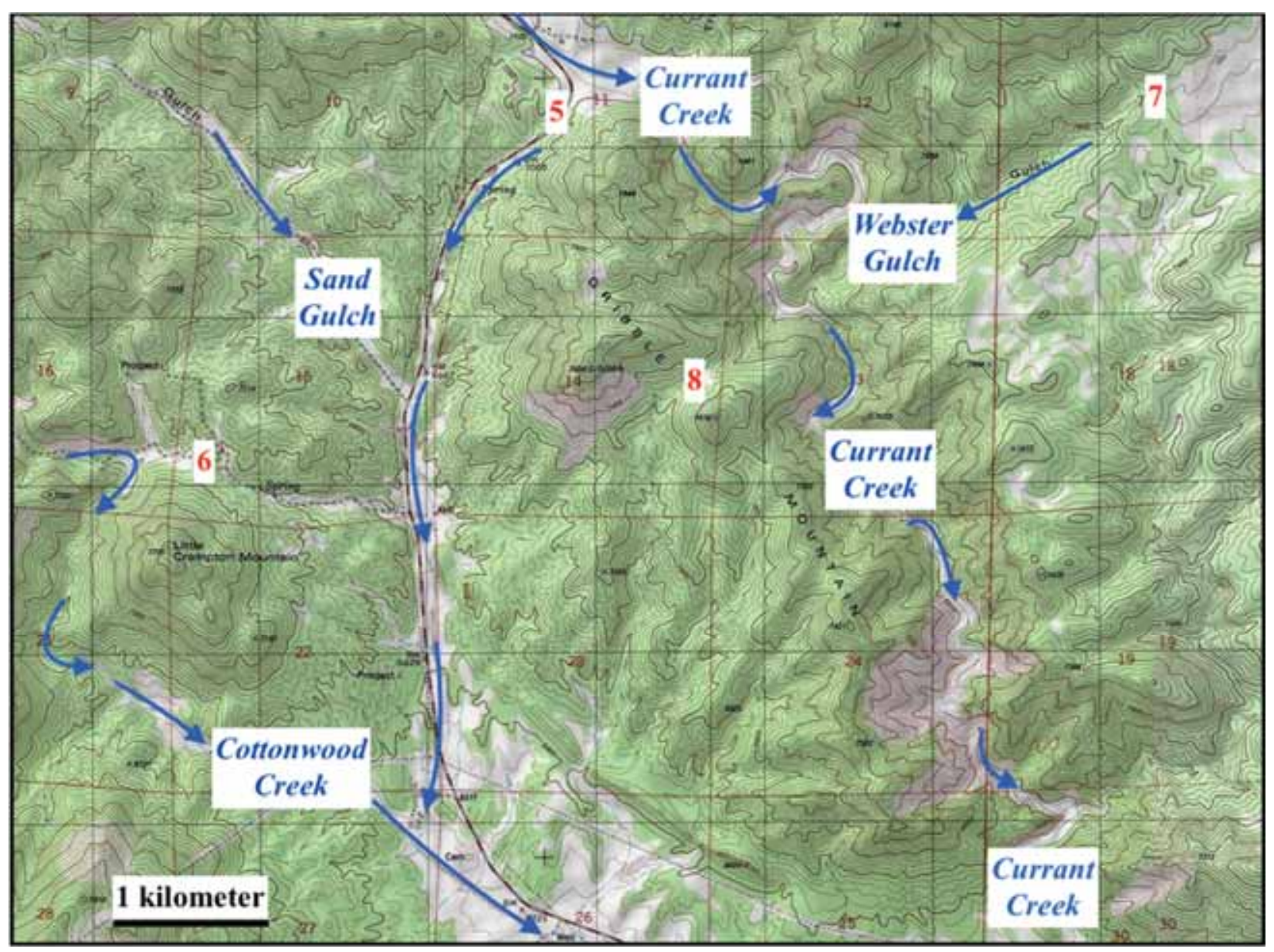

Figure 5. Modified topographic map from USGS National Map website showing diverging and converging valleys in the Griddle Mountain area (which is located north and west of figure 3). Numbers identify locations discussed in the text. The contour interval is 40 feet ( 12 meters).

The Arkansas River-Gulf of Mexico drainage divide now continues in a south-southeast direction from Poncha Pass along the Sangre de Cristo Mountain crestline into New Mexico and also serves as the Arkansas River drainage basin western boundary. As seen in figure 4 the Arkansas River flows for a distance in a southeast direction along the northern Sangre de Cristo Mountains eastern flank before turning in a northeast direction (rather than continuing in a south direction to flow into the Wet Mountain Valley). The Wet Mountain Valley is now drained by several different north- and northeast-oriented Arkansas River tributaries including Texas and Grape Creeks and the Huerfano, Cucharas, and Purgatoire Rivers and today low drainage divides separate northwest- or southeast-oriented tributaries or headwaters flowing to those north- and northeast-oriented Arkansas River tributaries while low points along those drainage divides suggest streams of water once flowed from the southeastoriented Arkansas River alignment into the Wet Mountain Valley and then southward along the Sangre de Cristo Mountain eastern flank. These streams of water must have been progressively captured from south to north by headward erosion the Purgatoire River, Cucharas River, Huerfano River, Grape Creek, and Texas Creek valleys. These captures probably occurred as deep "hole" rim uplift reversed flow directions and enabled north- and northeast-oriented valleys to erode headward into a developing Wet Mountain Valley. Deep "hole" rim uplift must have progressively diverted what were probably large and prolonged volumes of south-oriented water to flow in north and northeast directions.

The above interpretation suggests the deep "hole" rim followed the Sangre de Cristo Mountains crestline southward at least to the Purgatoire River-Canadian River drainage divide seen in figure 6. Like the Purgatoire River the Canadian River is an Arkansas River tributary, but unlike the Purgatoire River which turns in a northeast direction to join an east-oriented Arkansas River segment the Canadian River headwaters flow in south directions before turning in an east direction and the Canadian River does not have major northeast-oriented tributaries such 
as the northeast-oriented Arkansas River tributaries seen in figure 2. Instead, south of south-oriented Canadian River headwaters are south-oriented Pecos River headwaters with the Pecos River being a major Rio Grande River tributary. For these reasons, even though the Arkansas River-Gulf of Mexico drainage divide is located south of the Canadian River headwaters drainage basin the deep "hole" rim may have continued eastward from the Sangre de Cristo Mountains along the Purgatoire River-Canadian River drainage divide which in figures 6 and 7 appears to have deep "hole" rim characteristics (although further study is needed of the Canadian River-Pecos River drainage divide which is located to the south of this paper's study region).

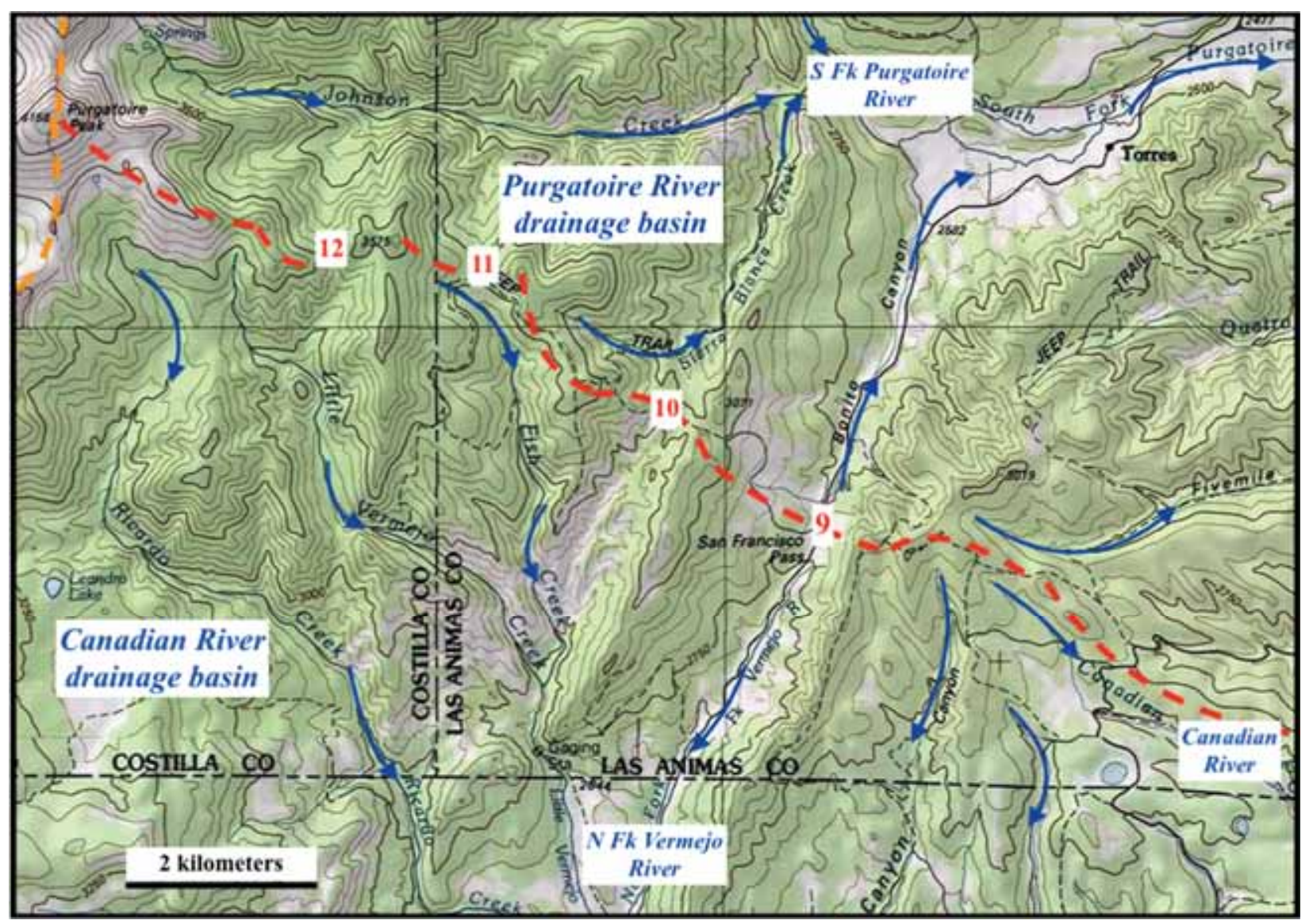

Figure 6. Modified topographic map from USGS National Map website showing the Purgatoire-Canadian River drainage divide (red dashed line) and in northwest corner the Arkansas-Rio Grande River drainage divide (orange dashed line). The Vermejo River is a south-oriented Canadian River tributary. Note southeast-oriented Canadian River headwaters in southeast quadrant. Numbers identify locations discussed in the text. Contour interval is 50 meters.

The Purgatoire River-Canadian River drainage divide is notched by numerous low points such as San Francisco Pass seen at location 9 in figure 6 and less prominent low points such as those seen at locations 10, 11, and 12. These low points indicate multiple streams of south-oriented water must have flowed across what is now a significant drainage divide with San Francisco Pass being located in the abandoned valley of a deep channel that entered today's Vermejo River drainage basin. South-oriented flood flow entering the Vermejo River drainage basin was captured further to the south by east-oriented Canadian River valley headward erosion. Labelled southeast-oriented Canadian River headwaters can be seen in the figure 6 southeast quadrant adjacent to and paralleling the Purgatoire-Canadian River drainage divide although which of these Canadian River headwaters streams received the Canadian River name was a map maker's decision. Continuing east from figure 6 the Purgatoire River-Canadian River drainage divide is a significant topographic barrier crossed by major transportation routes only at Raton Pass (number 13 in figure 7). Number 14 in figure 7 identifies a divide crossing where a southeast-oriented channel diverged from the deep channel responsible for eroding Raton Pass. Numbers $15,16,17,18$, and 18 identify shallower divide crossings and suggest that prior to erosion of the deep Raton Pass 
channel multiple closely spaced south-oriented flood flow channels crossed what is now a significant drainage divide. However further to the east the topographic barrier gradually disappears as the drainage divide crosses plains regions with much lower relief.

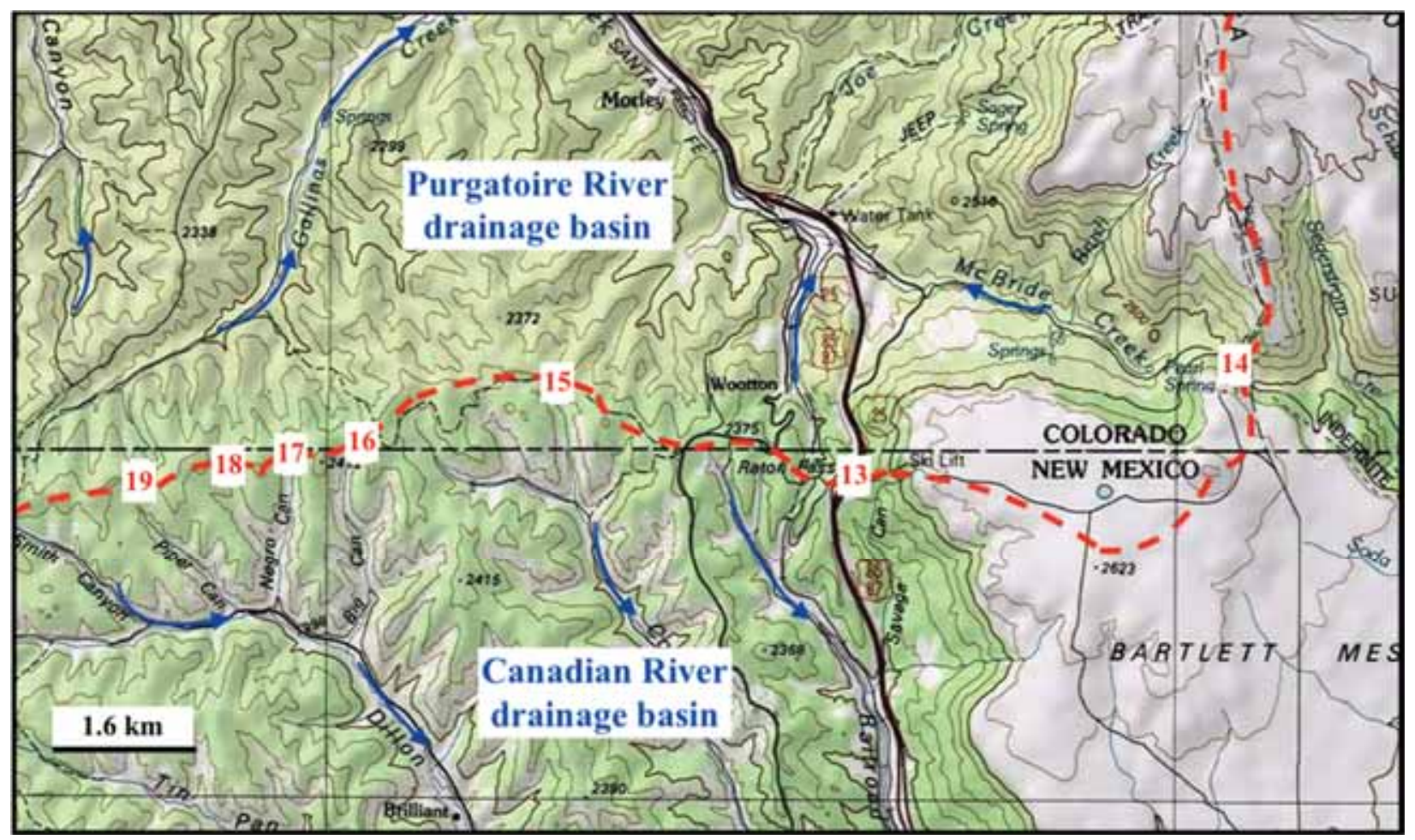

Figure 7. Modified topographic map from USGS National Map website showing Purgatoire-Canadian River drainage divide (red dashed line) in the Raton Pass (location 13) area. Numbers 14-19 identify other drainage divide low points discussed in text. Contour interval is 50 meters.

What is significant in figure 6 is the labelled Canadian River headwaters flow adjacent to and parallel to the drainage divide (although further to the east the Canadian River turns to flow in a south direction before turning to flow in an east direction again). The Canadian River and the Cimarron River (which to the east of figure 7 flows in an east direction between the Arkansas River and Canadian River-see figure 1) may be like the Sweetwater River which in central Wyoming flows along the Great Divide Basin's northern margin (see Clausen, 2019b). The deep "hole" rim in the Great Divide Basin area is not a well-defined mountain range crestline, but instead a broad high elevation region with relatively low relief. The east-oriented Sweetwater River valley probably eroded headward along the rising deep "hole" rim as deep "hole" rim uplift blocked south-oriented floodwaters and diverted the floodwaters eastward along the rising deep "hole" rim. The same situation may have occurred in the Great Plains region to the east of figure 7 with the east-oriented Cimarron and Canadian River valleys eroding headward as deep "hole" rim uplift blocked south-oriented flood flow to the Gulf of Mexico and forced floodwaters to flow in east directions toward what at that time was an actively eroding Arkansas River valley. If so, the deep "hole" rim location in the region to the east of the Sangre de Cristo Mountains may not continue along a single drainage divide, but instead may incorporate a broader region similar to Wyoming's poorly-defined Great Divide Basin deep "hole" rim location.

\section{Discussion}

The new paradigm was developed using Missouri River drainage basin topographic map evidence and did not include Arkansas River headwaters drainage basin topographic map evidence. In accordance with new paradigm predictions immense and prolonged south-oriented meltwater floods flowing across rising mountains in a large and ever changing south-oriented diverging and converging channel complex appear to explain most western Arkansas River drainage basin detailed topographic map drainage system and erosional landform features. Results reported here also point out the dangers of speculating about a region's drainage history before carefully studying that region's detailed topographic map drainage system and erosional landform evidence. Specifically, this author has speculated that the new paradigm's deep "hole" rim may have been located near the Missouri River-Arkansas 
River drainage divide. As seen in this paper's results section after studying the western Arkansas River drainage basin topographic map evidence this author is now convinced the deep "hole" rim continued southward from the east-west continental divide along the Sangre de Cristo Mountain crestline at least to the Purgatoire RiverCanadian River drainage divide and the deep "hole" rim location to the east of that point may have been continued along the Purgatoire River-Canadian River drainage divide at least as far as Raton Pass (seen in figure 7). However, further study is needed to determine whether the deep "hole" rim continued east along the Purgatoire RiverCanadian River drainage divide (shown in figure 7) or more closely followed what is now the Canadian River-Rio Grande River drainage divide and also to better determine the deep "hole" rim location in the Great Plains region to the east of the Rocky Mountains.

The new and accepted paradigms using Kuhn's (1970) terminology are incommensurable, which means the two paradigms are different and cannot be judged by a common standard. For that reason, new paradigm demonstration papers (such as this paper) do not use the accepted paradigm's geologic time scale or absolute age dates. New paradigm geologic and glacial histories are determined by the use of relative age dating techniques which make use of topographic map drainage system evidence to determine valley formation sequences. Topographic map evidence can also be combined with geologic map evidence to determine where flood eroded channels cut into previously mapped geologic units and/or contain previously mapped sediments. As described in Clausen (2021a) large floods flowing from the South Platte River headwaters area (to the north of Royal Gorge) in addition to having occurred as regional and mountain uplift was occurring may have occurred while intense volcanic activity affected the region (which from the accepted paradigm perspective probably occurred during Oligocene time). And as described in Clausen (2019a) previously mapped middle Tertiary sediments are found in flood eroded northern Laramie Mountains valleys. At the same time the new paradigm only sees evidence for two linked continental ice sheets. The first ice sheet (which was located where continental ice sheets are usually reported to have been) was thick and heavy and by deep ice sheet erosion and crustal warping (which uplifted surrounding mountain ranges and regions) created and occupied a deep "hole". A second ice sheet formed in the deep "hole" when first ice sheet melting opened up deep "hole" space, which permitted north-oriented valleys to erode headward from the deep "hole" and divert meltwater floods from the Gulf of Mexico to the North Atlantic and Arctic Oceans. This diversion of meltwater floods and other drainage changed the climate and caused northoriented drainage to freeze around decaying first ice sheet remnants and to create a much thinner second continental ice sheet. In other words, the two paradigms lead to different and incommensurable geologic and glacial histories. Kuhn (1970) advises that when comparing competing paradigms what is important is how well each of the paradigms explains the observed evidence and opens up new research opportunities.

\section{Conclusions}

Large and prolonged south-oriented floods flowing through a rising Royal Gorge area appear to explain most if not all of the regional diverging and converging valleys, barbed tributaries, and abrupt drainage route direction changes seen on USGS detailed topographic maps. Such immense floods are consistent with new paradigm predictions describing the Royal Gorge region as being near the rim of a continental ice sheet created deep "hole" with that deep "hole" rim being uplifted as massive and prolonged meltwater floods flowed across the region. The deep "hole" rim continued southward from the east-west continental divide in the Arkansas River headwaters area along the Sangre de Cristo Mountains crestline at least to the Purgatoire River-Canadian River drainage divide and then may have continued eastward in a less well-defined broad zone between south-oriented drainage to the Gulf of Mexico and east-oriented drainage to the Mississippi River (which may include areas now drained by the eastoriented Cimarron and Canadian Rivers-both of which flow to the Arkansas River and then to the Mississippi River). While explaining detailed topographic map drainage system and erosional landform evidence the new paradigm leads to a significantly different Cenozoic geologic and glacial history than geologists working from the accepted paradigm perspective have constructed. Further work is needed to flesh out new paradigm details such as additional deep "hole" rim locations between the Sangre de Cristo Mountains and the Mississippi River valley and to better understand how the new paradigm describes Cenozoic geologic and glacial history.

\section{Acknowledgements}

New paradigm development began while employed as a Minot State University faculty member where other faculty members, students, and library staff greatly assisted with access to needed topographic maps. During the mid 1960s Arthur Strahler, then at Columbia University, and Brainerd "Nip" Mears, Jr., then at the University of Wyoming introduced the author to numerous unsolved drainage history problems. 


\section{References}

Abbey, A. L., Niemi, N. A., Geissman, J. W., Winkelstern, I. Z., \& Heizler, M. (2018). Early Cenozoic exhumation and paleotopography in the Arkansas River valley, southern Rocky Mountains, Colorado. Lithosphere, 10(2), 239-266. https://doi.org/10.1130/1673.1

Atwood, W. W. (1940). The Physiographic Provinces of North America. Ginn and Company, New York, 536 p.

Clarey, T. L., Chase, R. B., \& Schmidt, C. J. (2004). Precambrian influences on the development of the Royal Gorge Arch, Colorado: A thick-skinned fault-propagation fold. The Mountain Geologist, 41(1), 17-32.

Clausen, E. (2018). Topographic map analysis of Laramie Range bedrock-walled canyon complex and the Goshen Hole escarpment-surrounded basin, Albany and Platte Counties, southeast Wyoming, USA. Open Journal of Geology, 8, 33-55. https://doi.org/10.4236/ojg.2018.81003

Clausen, E. (2019a). Use of stream and dismembered stream valleys now crossing Wyoming's northern Laramie Mountains to test a recently proposed regional geomorphology paradigm, USA. Open Journal of Geology, 9, 731-751. https://doi.org/10.4236/ojg.2019.911087

Clausen, E. (2019b). Use of topographic map evidence from drainage divides surrounding Wyoming's Great Divide Basin to compare two fundamentally different regional geomorphology paradigms. Earth Science Research, 9(1), 45-57. https://doi.org/10.5539/esr.v9n1p45

Clausen, E. (2020a). Analyzing anomalous topographic map drainage system and landform evidence as a glacial history paradigm problem: a literature review. Open Journal of Geology, 10, 1072-1090. https://doi.org/10.4236/ojg.2020.1011052

Clausen, E. (2020b). Topographic map analysis of mountain passes crossing the continental divide between Colorado River headwaters and North and South Platte River headwaters to test a new geomorphology paradigm, Colorado, USA. Journal of Geography and Geology, 12(1), 50-64. https://doi.org/10.5539/jgg.v12n1p50

Clausen, E. (2021a). How a new geology and glacial paradigm explains South Platte-Arkansas River drainage divide topographic map evidence, US. Open Journal of Geology, 11, 573-595. https://doi.org/10.4236/ojg.2021.1111029

Clausen, E. (2021b). Topographic map analysis of the North Platte River-South Platte River drainage divide area, western Larimer County, Colorado, USA. Earth Science Research, 10(1), 49-60. https://doi.org/10.5539/esr.v10n1p49

Davis, W. M. (1911). The Colorado Front Range, a study on physiographic presentation. Annals of the Association of American Geographers, 1, 21-83. https://doi.org/10.2307/2560844

Epis, R. C., Scott, G. R., Taylor, R. B., \& Chapin, C. E. (1976). Cenozoic volcanic, tectonic, and geomorphic features of central Colorado: In Epis, R. C. and Weimer, R. J., eds., Studies in Colorado Field Geology. Colorado School of Mine Professional Contributions, 8, 301-322.

Epis, R. C., Scott, G. R., Taylor, R. B., \& Chapin, C. E. (1980). Summary of Cenozoic geomorphic volcanic and tectonic features of Central Colorado and adjoining areas. In Kent, H. C. and Porter, K. W., eds., Colorado Geology. Rocky Mountain Association of Geologists, 135-156.

Fenneman, N. N. (1931). Physiography of the Western United States. McGraw-Hill Book Company, Inc., 534.

Gregory, K. M. \& Chase, C. G. (1994). Tectonic and climatic significance of a late Eocene low-relief, high-level geomorphic surface, Colorado. Journal of Geophysical Research, 99, 20, 14120-160. https://doi.org/10.1029/94jb00132

Kellogg, K. S., Shroba, R. R., Ruleman, C. A., Bohannon, R. G., McIntosh, W. C., et al. (2017). Geologic map of the upper Arkansas River Valley region, north-central Colorado. United States Geological Survey Scientific Investigations 3382 Map and Pamphlet. 70. https://doi.org/10.3133/sim3382

Knepper, D. H. (1976). Late Cenozoic structure of the Rio Grande rift zone, central Colorado. In Epis, R. C. and Weimer, R. J., eds., Studies in Colorado Field Geology. Colorado School of Mines Professional Contributions, $8,421-430$.

Kuhn, T. S. (1970). The Structure of Scientific Revolutions: second edition, enlarged. University of Chicago Press, Chicago. 210. 
Leonard, E. M., Hubbard, M. S., Kelley, S. A., Evanoff, E., Siddoway, Oviatt, C. G., Heozler, M., \& Timmons, M. (2002). High Plains to Rio Grande Rift: Late Cenozoic Evolution of Central Colorado. In Lageson, D. ed., Science at the Highest Level. Geological Society of America Field Guide, volume 3, 59-93.

Love, J. D. (1970). Cenozoic geology of the Granite Mountains area, central Wyoming. United States Geological Survey Professional Paper 495-C, 154. https://doi.org/10.3133/pp495c

Pazzaglia, F. J. \& Kelley, S. A. (1998). Large-scale geomorphology and fission-track thermochronology in topographic and exhumation reconstructions of the Southern Rocky Mountains. Rocky Mountain Geology, 33(2), 229-257. https://doi.org/10.2113/33.2.229

Powers, W. E. (1935). Physiographic history of the upper Arkansas Valley and the Royal Gorge, Colorado. Journal of Geology, 43(2), 184-199. https://doi.org/10.1086/624287

Scott, G. R. \& Epis, R. (1977). Canon City area: Colorado Scientific Society spring field trip, April 15, 1977. Unpublished field guide, 8.

Taylor, R. B., Scott, G. R., Wobus, R. A. \& Epis, R. C. (1975). Reconnaissance geologic map of the Royal Gorge Quadrangle, Fremont and Custer Counties, Colorado. United States Geological Survey Miscellaneous Investigations Map I-869, scale 1:62, 500, 1 sheet.

Thornbury, W. D. (1965). Regional Geomorphology of the United States. John Wiley \& Sons, Inc., New York, 609. https://doi.org/10.1097/00010694-196508000-00018

United States Geological Survey National Map website. (accessed November, 2021). https://apps.nationalmap.gov/viewer/

Van Tuyl, F. M. \& Lovering, T. S. (1935). Physiographic development of the Front Range. Bulletin of the Geological Society of America, 46, 1291-1350. https://doi.org/10.1130/GSAB-46-1291

\section{Copyrights}

Copyright for this article is retained by the author(s), with first publication rights granted to the journal.

This is an open-access article distributed under the terms and conditions of the Creative Commons Attribution license (http://creativecommons.org/licenses/by/4.0/). 